\title{
Intrauterine low protein diet increases fetal $\beta$-cell sensitivity to NO and IL-1ß: the protective role of taurine
}

\author{
S Merezak, A A Hardikar ${ }^{1}$, C S Yajnik², C Remacle \\ and $\mathbf{B}$ Reusens
}

Laboratory of Cell Biology, World Health Organization Collaborating Center for the Biology of Development of the Endocrine Pancreas, Université Catholique
de Louvain, B-1348 Louvain-La-Neuve, Belgium
${ }^{1}$ Tissue Engineering and Banking Laboratory, National Center for Cell Science, Ganeshkhind, Pune 411007, India
${ }^{2}$ Diabetes Research Center, KEM Hospital, Rasta peth, Pune 411001, India
(Requests for offprints should be addressed to B Reusens, Laboratoire de Biologie Cellulaire, Université Catholique de Louvain, Place croix du sud 5,
1348 Louvain-La-Neuve, Belgium; Email: reusens@bani.ucl.ac.be)

\begin{abstract}
We have demonstrated earlier that a low-protein $(8 \%$ protein) diet during gestation alters fetal $\beta$-cell development. Here, we investigated the effect of a low-protein diet as compared with a control (20\% protein) diet, during gestation, on the sensitivity of fetal $\beta$-cells against nitric oxide (NO) or interleukin-1 $\beta$ (IL-1 $\beta$ ), and assessed the protective effect of taurine in vitro and in vivo. Neoformed islets from control fetuses or fetuses of dams fed a lowprotein diet (LP group) were incubated with taurine, methionine or $\beta$-alanine and then exposed to sodium nitropruside (SNP), a NO donor, or to IL-1 $\beta$. To understand the effect of taurine in vivo, LP or control pregnant rats received $2.5 \%$ of taurine in the drinking water. Mortality and rate of apoptosis were quantified by confocal microscopy. Without treatment, rate of apoptosis was greater in LP group islets than in control islets $(1 \cdot 38 \pm 0 \cdot 18 \%$ compared with $0 \cdot 66 \pm 0 \cdot 21 \%$ respectively,
\end{abstract}

$P<0 \cdot 05)$. Addition of SNP $100 \mu \mathrm{M}$ showed an augmentation in cell death, which was greater in the LP than in the control group (17·88 $\pm 0 \cdot 69 \%$ compared with $11 \cdot 89 \pm 0 \cdot 44 \%$ respectively, $P<0 \cdot 01)$. LP islets were more sensitive than control islets to IL-1 $\beta$. Taurine was protective against SNP and IL-1 $\beta$ in both the groups, methionine provided a less protective effect than taurine, and pretreatment with $\beta$-alanine had no protective effect. Taurine supplementation of the maternal diet reduced the rate of apoptosis induced by IL-1 $\beta$ in control islets and suppressed that induced by IL-1 $\beta$ in LP islets. Our findings indicate that a low-protein diet during gestation augments the sensitivity of fetal islet cells to NO and IL-1 $\beta$. However, through in vitro and in vivo experiments our studies indicate that such effects can be rescued using amino acids such as taurine.

Journal of Endocrinology (2001) 171, 299-308

\section{Introduction}

Recent epidemiological findings suggest that several adult diseases, including diabetes, may originate in the womb (Barker et al. 1993, Barker 1998). Intrauterine malnutrition has been known to induce alterations in the development of several tissues, among which are the endocrine pancreas. Indeed, a low-protein diet given to the dams throughout gestation has been shown to decrease islet cell proliferation, islet size and pancreatic insulin content in the progeny at birth (Snoeck et al. 1990). It also leads to a reduced insulin secretion from fetal islet in vitro (Dahri et al. 1991). Moreover, apoptosis is increased in these fetal and neonatal $\beta$-cells (Petrik et al. 1999). Likewise, in the rat, general food restriction during gestation leading to intrauterine growth retardation, decreases the $\beta$-cell mass and the pancreatic insulin content at birth (Garofano et al. 1997). In addition, apoptosis of the $\beta$-cell is enhanced at 3 months even after an adequate quantity of food is given after weaning (Garofano et al. 1998).

The $\beta$-cells are exceedingly sensitive to different molecules such as streptozotocin (Bonner-Weir et al. 1981) or nitric oxide (NO) and cytokines involved in $\beta$-cell destruction as seen in insulin-dependent diabetes mellitus (Mandrup-Poulsen 1996). Interleukin IL-1 $\beta$, alone or in combination with tumor necrosis factor- $\alpha$ (TNF- $\alpha$ ) and interferon- $\gamma($ IFN- $\gamma$ ), demonstrates a cytotoxic activity on $\beta$-cells cultured in vitro that is partly mediated through the induction of free radicals such as NO (Cetkovic \& Eizirik 1994). The production of NO is catalyzed by inducible nitric oxide synthase (iNOS) (Corbett et al. 1991). The release of NO in $\beta$-cells leads to apoptosis and, subsequently, to characteristic DNA fragmentation and cell 
death (Delaney et al. 1993, 1997, Fehsel et al. 1993). Consequently, the first aim of this study was to determine if a low-protein diet given to the dams during gestation (inducing altered fetal $\beta$-cell mass) increased the susceptibility of fetal $\beta$-cells to cytotoxic damage such as that induced by IL-1 $\beta$ and by a NO donor.

We have also shown previously that the level of taurine (2-amino ethanesulphonic acid) is markedly reduced in the plasma of fetuses of dams fed a low-protein diet (Reusens et al. 1995). Taurine supplementation of the low-protein diet of the mother restored a normal taurine concentration in fetal plasma, and a normal insulin secretion by fetal islets (Cherif et al. 1998). Taurine also restored a normal proliferation rate in $\beta$-cells of fetuses of dams fed a low-protein diet (Boujendar et al. 1999, 2000). Taurine, a $\beta$-amino acid derived from methionine and cysteine metabolism, is the most abundant intracellular free amino acid present in mammalian cells (Jacobsen \& Smith 1968). This sulphonated $\beta$ amino acid is also present at high concentration in the endocrine pancreas (Bustamante et al. 1998). Among the several properties of taurine, this semi-essential amino acid is also known to serve as an antioxidant agent (Huxtable 1992). The role of taurine against oxidative damage has been described in variety of cell types. This amino acid, possibly through its antioxidant activity and regulation of intracellular calcium flux can prevent the death of endothelial cells (Wang et al. 1996). Taurine has also been shown to attenuate apoptosis and necrosis of hepatocytes (Redmong et al. 1996) and inhibit the production of nitric oxide by glioma cells (Liu et al. 1998). Thus the second aim of this study was to determine if taurine, added in vivo to the drinking water of these dams or in vitro in the culture medium, could provide prevention of and protection against cytotoxic damage in fetal $\beta$-cells from control dams and dams fed a low-protein diet treated with IL-1 $\beta$ or NO.

\section{Materials and Methods}

\section{Animals}

Adult virgin female Wistar rats were caged overnight with males and copulation was verified the next morning. The animals were maintained at $25{ }^{\circ} \mathrm{C}$ with a $10 \mathrm{~h}$ darkness: $14 \mathrm{~h}$ light cycle. One group of pregnant rats was fed a control diet (20\% protein) and a second group received an isocaloric low-protein diet $(8 \%$ protein; LP group). The compositions of these diets have been described previously (Snoeck et al. 1990); these diets are devoid of taurine but the $20 \%$ protein diet contained $0 \cdot 2 \%$ methionine whereas the low-protein diet contained only $0 \cdot 08 \%$. The diets were purchased from Hope Farms (Woerden, Holland). Animals in both groups had free access to water. On day 21.5 of gestation, females were killed by decapitation and fetuses removed.
To investigate the effect of taurine in vivo, the pregnant rats were fed a control or low-protein diet supplied with $2.5 \%(\mathrm{w} / \mathrm{v})$ of taurine in the drinking water throughout gestation.

\section{Islet culture and treatment}

Fetal pancreata were dissected and digested with collagenase as described previously (Mourmeaux et al. 1985). The cell suspension was cultured in $35 \mathrm{~mm}$ Petri dishes (Falcon plastics, Los Angeles, CA, USA) in RPMI 1640 medium (Gibco, Grand Island, NY, USA) with fetal bovine serum $(10 \%)$ and antibiotics (penicillin $200 \mathrm{U} / \mathrm{ml}$, streptomycin $0 \cdot 2 \mathrm{mg} / \mathrm{ml}$ ). Petri dishes were incubated at $37^{\circ} \mathrm{C}$ with $5 \% \mathrm{CO}_{2}$ in air. The culture medium was changed daily after the second day. These cultures provided islets that aggregated progressively on the layer of non-endocrine cells.

\section{Islet treatment}

On the 5th day of culture, the dishes were rinsed twice with serum-free DMEM/F12 medium (1:1 v/v, Gibco, Paisley, Strathclyde, UK) and then incubated for next $42 \mathrm{~h}$ in the same medium without or with taurine $(0.3$ or $3 \mathrm{mM})$, methionine $(0 \cdot 1$ or $1 \mathrm{mM})$ or $\beta$-alanine $(0.3$ or $3 \mathrm{mM}$ ) (Sigma Chemical Co., St Louis, MO, USA). During the last $18 \mathrm{~h}$ of treatment, the islets were exposed to 10 or $100 \mu \mathrm{M}$ sodium nitropruside (SNP; Sigma Chemical Co.).

In other experiments, the islets were treated with 0.3 or $3 \mathrm{mM}$ taurine for $48 \mathrm{~h}$ and exposed to IL-1 $\beta$ (Endogen, Woburn, MA, USA) at $50 \mathrm{U} / \mathrm{ml}$ for the last $24 \mathrm{~h}$.

\section{Islet labelling}

Apoptosis was visualized as DNA strand breaks by TUNEL methodology (Li et al. 1995), using BODIPYFL-X-14-dUTP (Molecular Probes, Eugene, OR, USA) to label the apoptotic nuclei. Propidium iodide (Molecular Probes) was used to label the total islet nuclei.

Global cell death was analysed using a non-specific probe staining the dead cells, the plasma membranes of which became permeabilized. For this purpose, the culture medium was removed and the dishes washed with phosphate buffered saline (PBS). These were then incubated for $20 \mathrm{~min}$ with $1 \mathrm{ml}$ culture medium containing $20 \mu \mathrm{g} / \mathrm{ml}$ ethidium bromide to stain the permeabilized dead cells. The cultures were then fixed with $4 \%$ paraformaldehyde in PBS for 10 min, treated with 30\% methanol for permeabilization of the remainder of the cells and then mounted in mowiol containing $20 \mu \mathrm{g} / \mathrm{ml}$ of Hoechst 33342 , to stain the nuclei of all the cells.

\section{Confocal microscopy}

Staining probes were visualized through a confocal laser scanning microscopy system (MRC-1024 UV; Bio-Rad, 
Hemel Hempstead, Herts, UK) equipped with argon ion and krypton/argon ion lasers. BODIPY-FL was excited at $503 \mathrm{~nm}$ and emitted at $522 \pm 32 \mathrm{~nm}$, ethidium bromide was excited at $510 \mathrm{~nm}$ and emitted at $605 \pm 32 \mathrm{~nm}$, propidium iodide was excited at $536 \mathrm{~nm}$ and emitted at $605 \pm 32 \mathrm{~nm}$ and Hoechst 33342 was excited at $346 \mathrm{~nm}$ and emitted at $455 \pm 30 \mathrm{~nm}$. Four to six optical sections were collected at every $15 \mu \mathrm{m}$ through the entire length of the islet. The number of BODIPY-FL- or ethidium bromide-positive nuclei were expressed as percentage of the total number of nuclei.

\section{Nitrite assay}

We quantified the concentration of NO in an acellular system in the presence of SNP alone or with taurine. Nitrite, a stable end product of $\mathrm{NO}$ oxidation, was measured by a fluorimetric procedure, based upon the reaction of nitrite with the 2,3-diaminonaphthalene (DAN) (Molecular Probes) to form the fluorescent product, 1-(H)-naphthotriazole (Misko et al. 1993). This method allows measurement of nitrite in concentrations of as little as $10 \mathrm{nM}$. In order to measure total NO production in the culture media, nitrate was converted to nitrite by the action of nitrate reductase from Aspergillus species (Sigma). The sample $(100 \mu \mathrm{l})$ was incubated with $100 \mu \mathrm{l}$ $20 \mathrm{mM}$ Tris buffer, $\mathrm{pH} 7 \cdot 6$ containing, in final concentration, $80 \mu \mathrm{M} \mathrm{NADPH}$ (to initiate the reaction) and $56 \mathrm{mU}$ enzyme. The reaction was stopped after $5 \mathrm{~min}$ of incubation at room temperature by dilution with $1800 \mu \mathrm{l}$ ultrapure water, followed by the addition of DAN reagent $(200 \mu \mathrm{l}$ of a $0.05 \mathrm{mg} / \mathrm{ml}$ solution in $0.62 \mathrm{M} \mathrm{HCl})$. Finally, $100 \mu \mathrm{l} 2 \cdot 8 \mathrm{M} \mathrm{NaOH}$ was added to each sample. Nitrite concentration was determined by using sodium nitrite (Sigma) as a standard. The fluorescence was measured in a Kontron fluorimeter. The excitation and emission wavelengths were $365 \mathrm{~nm}$ and $450 \mathrm{~nm}$ respectively.

\section{Chemiluminescence measurements}

Luminol (5-amino-2,3-dihydro-1-4-phthalazinedione, Sigma; $400 \mu \mathrm{M})$, taurine $(0 \cdot 3$ or $3 \mathrm{mM})$, methionine $(0 \cdot 1$ or $1 \mathrm{mM})$ and $\beta$-alanine $(0.3$ or $3 \mathrm{mM})$ stock solutions were prepared in PBS. 3-Morpholinosydnonimine (SIN-1; Sigma) at $100 \mu \mathrm{M}$ was prepared in $\mathrm{NaOH} 1 \mathrm{M}$. The reaction was initiated by simultaneous injection of luminol and SIN-1 in the wells containing or not containing the amino acids in PBS. Chemiluminescence emitted by luminol in the presence of peroxynitrite was measured every $30 \mathrm{~s}$ during $20 \mathrm{~min}$ in the chemifluorophotometer (MicroLumat LB96P, EG \& G Berthold).

\section{HPLC measurements}

Islets were incubated overnight at $+4^{\circ} \mathrm{C}$ in $35 \%$ 5 -sulphosalicylic acid in order to extract the amino acids.

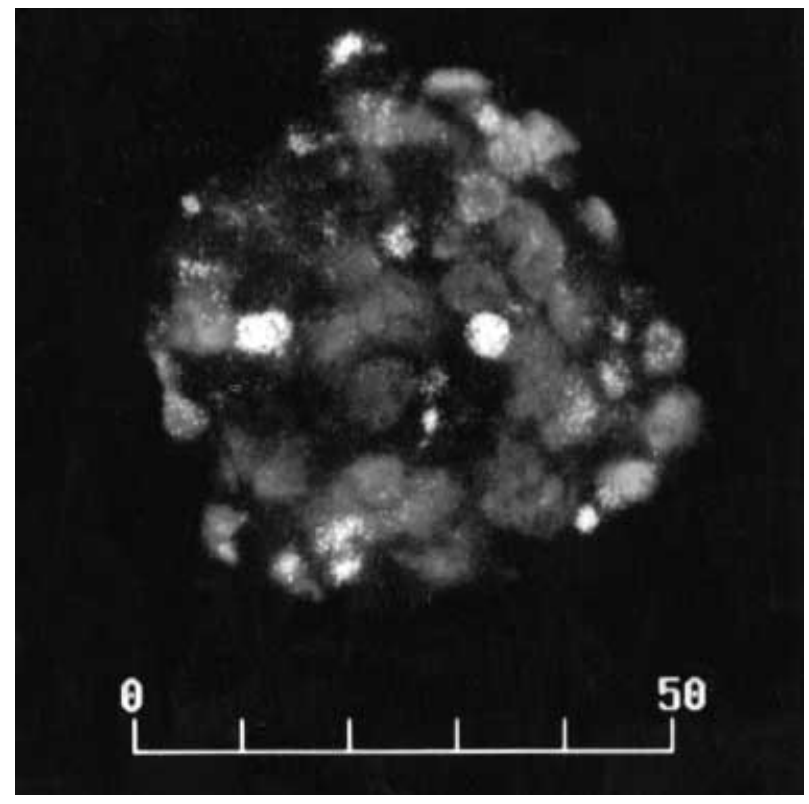

Figure 1 Confocal micrograph showing apoptotic nuclei labelled with BODIPY-FL-dUTP (in white) and total nuclei labelled with propidium iodide (in grey). Scale bar represents $50 \mu \mathrm{m}$.

Their separation and quantification were performed with a standard, reverse phase HPLC method after derivatization with o-phthalaldehyde.

\section{Statistical analysis}

Experimental results are reported as means \pm s.E.M. Significance of the differences between groups was analysed by Scheffé's test after one- or two-way ANOVA.

\section{Results}

Culture of control and LP group islets: apoptosis and taurine content

The culture of fetal pancreas provides islets that are exclusively composed of endocrine cells, of which $>95 \%$ are $\beta$-cells (Mourmeaux et al. 1985). Apoptosis was quantified in the fetal islets by counting the nuclei labeled by a TUNEL method, on confocal sections (Fig. 1). Islet cell apoptosis was significantly greater in the LP group $(1 \cdot 38 \pm 0 \cdot 2 \%, P<0 \cdot 001)$ than in the controls $(0 \cdot 66 \pm 0 \cdot 2 \%$, $P<0 \cdot 001)$.

The concentration of taurine in islets after 7 days of culture was measured by HPLC. LP group islets showed a significantly $(P<0 \cdot 01)$ lower concentration of taurine $(22.9 \pm 1.5 \mathrm{mM} / \mu \mathrm{g}$ protein) as compared with control islets $(36 \cdot 9 \pm 5 \cdot 2 \mathrm{mM} / \mu \mathrm{g}$ protein). 


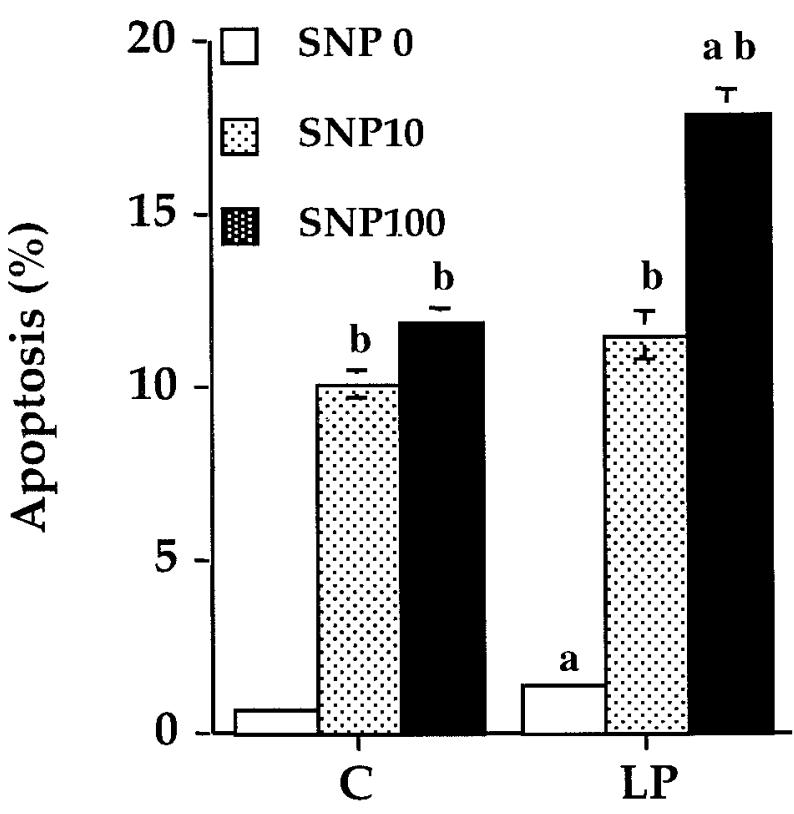

Figure 2 Effect of a low-protein diet on the sensitivity of control (C) and LP group islets towards SNP, a chemical donor of NO. Islets were cultured for 6 days in RPMI 1640 medium and then treated for $18 \mathrm{~h}$ without SNP (SNP 0) or with SNP 10 or $100 \mu \mathrm{M}$ (SNP10, SNP100). Apoptosis was quantified by confocal microscopy using a TUNEL method. Values are the means of 11-14 islets pooled from three separate experiments with at least 2600 cells/group. ${ }^{a} P<0 \cdot 01$ compared with control; ${ }^{b} P<0 \cdot 01$ compared with SNP 0.

\section{SNP-induced apoptosis in fetal $\beta$-cells of control and LP groups}

When the islets were incubated with 10 or $100 \mu \mathrm{M}$ of the NO donor SNP, the rate of apoptosis increased acutely in a dose-dependent manner (Fig. 2). With $100 \mu \mathrm{M}$ SNP, apoptosis was significantly greater in LP islet cells than in controls. To confirm these results, we measured the percentage mortality in response to $100 \mu \mathrm{M}$ SNP, using a test for cell permeability to ethidium bromide. LP group fetal islets showed $10 \cdot 4 \pm 0 \cdot 7 \%$ mortality, whereas in control islets the mortality was only $2 \cdot 9 \pm 0 \cdot 8 \%$, which corroborated the results obtained using the TUNEL method.

\section{Effect of taurine, methionine and $\beta$-alanine on SNP-induced apoptosis}

In the second series of experiments, control fetal islets treated for $42 \mathrm{~h}$ with $0.3 \mathrm{mM}$ or $3 \mathrm{mM}$ taurine showed rates of apoptosis of $1.5 \pm 0 \cdot 2 \%$ and $1 \cdot 4 \pm 0 \cdot 3 \%$ respectively, which are not significantly different from those of control islets without taurine $(1 \cdot 3 \pm 0 \cdot 2 \%)$. In LP group islets, the percentage of apoptotic cells was approximately twofold greater $(2 \cdot 2 \pm 0 \cdot 3 \%)$ as in the previous series and taurine did not affect this basal rate $(2 \cdot 1 \pm 0 \cdot 3 \%$ and $2 \cdot 1 \pm 0 \cdot 4 \%$ respectively with $0 \cdot 3$ and $3 \mathrm{mM}$ of taurine).
The protective effect of taurine against SNP cytotoxicity is presented in Fig. 3a. At physiological or supraphysiological concentrations, taurine significantly decreased the percentage of islet cells positive for apoptosis in both groups. However the protective effect of physiological concentrations of taurine was more marked in the LP islets (60\% reduction of apoptosis compared with 30\% in controls).

To determine if the activity of taurine was specific to this amino acid, we compared its effect with that of methionine, another sulphur-containing amino acid. In both groups (control and LP) the percentage of islet cells positive for apoptosis was significantly lower when methionine was used at physiological concentration (Fig. 3b). At supraphysiological concentration, methionine did not provide additional protection.

To determine the role of the sulphur moiety in the protective effect of taurine, $\beta$-alanine, an analogue of taurine lacking the sulphur moiety, was added in the same test conditions. The rate of apoptosis was similar with or without $\beta$-alanine, indicating that it afforded no protective effect against the toxicity of NO (Fig. 3c).

The protective activity of taurine was also verified by quantification of cell death using the cell-permeant probe. Figure 4 shows that the percentage of cell death was significantly diminished when islet cells were pretreated with taurine at physiological and supraphysiological concentrations. This was true for both groups, and this effect was dose dependent.

\section{Interaction of taurine and $\mathrm{NO}$}

Nitric oxide is a reactive free radical that leads to peroxynitrite formation, another particularly reactive free radical, by interaction with superoxide $\left(\mathrm{NO}+\mathrm{OO}^{\bullet} \rightarrow\right.$ $\mathrm{ONOO}^{\bullet}$ ). In order to determine if taurine had to act on islet cells in order to exert its protective effect or, alternatively, if the amino acid acted extracellularly, we investigated the possible direct molecular interaction between taurine and the NO donor, in addition to the formation of peroxynitrite. We then quantified the concentration of $\mathrm{NO}$ in an acellular system in the presence of SNP alone or with taurine. The concentration of NO released by SNP reached $26.7 \mathrm{nmol} / \mathrm{ml}$ and was not significantly different when taurine was added in a concentration of $0.3 \mathrm{mM} \quad(26.8 \mathrm{nmol} / \mathrm{ml})$ or $3 \mathrm{mM}$ $(26.7 \mathrm{nmol} / \mathrm{ml})$. To investigate the possibility that taurine decreased the formation of peroxynitrite from $\mathrm{NO}$, we used luminol-derived chemiluminescence induced by peroxynitrite produced by the decomposition of sydnonimine (SIN-1). The effects of the addition of taurine $(0.3$ or $3 \mathrm{mM})$, methionine $(0.1$ or $1 \mathrm{mM})$ or $\beta$-alanine $(0.3$ or $3 \mathrm{mM})$ to this system are shown in Fig. 5 . With $3 \mathrm{mM}$ of taurine, luminol chemiluminescence was markedly decreased. No change was observed when the other amino acids were added. 


\section{a) Taurine}

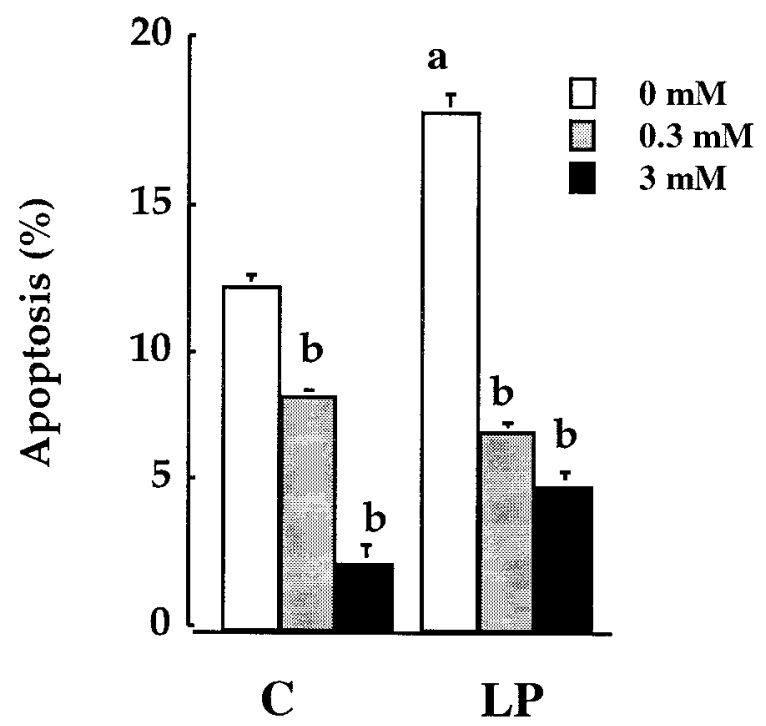

b) Methionine

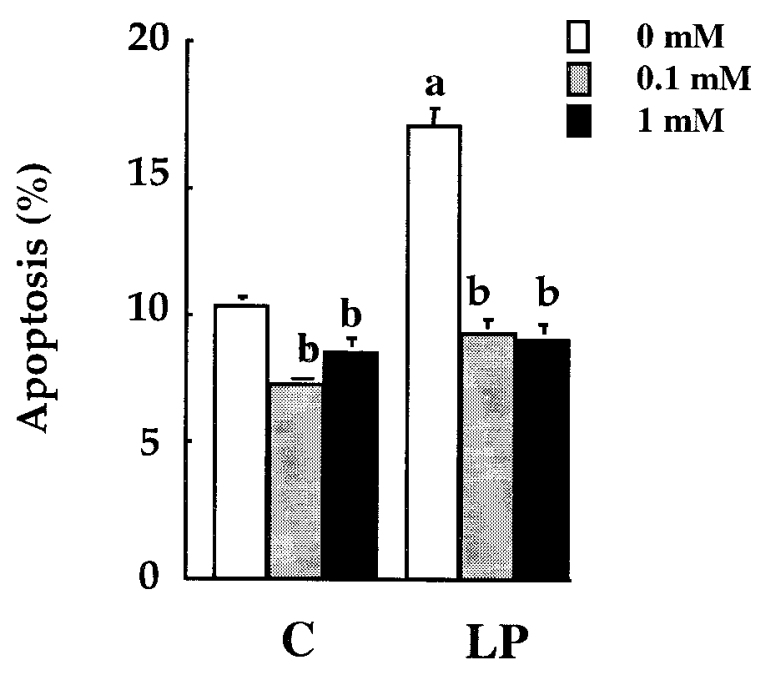

Effect of taurine on IL- $\beta$-induced apoptosis

In this series of experiments, the basal rate of apoptosis in both groups was somewhat greater than that in the previous experiment (Fig. 6). Incubation of fetal islets with $50 \mathrm{U} / \mathrm{ml} \mathrm{IL}-1 \beta$ for $24 \mathrm{~h}$ increased the level of apoptosis in the control group and even more in the LP group.

To evaluate the protective effect of taurine against IL-1 $\beta$-induced apoptosis, islets were pretreated with taurine for $24 \mathrm{~h}$ and then exposed to IL-1 $\beta$ for $24 \mathrm{~h}$. In control islets, only the high dose of taurine significantly decreased the rate of apoptosis, but in LP group islets, c) $\beta$-alanine

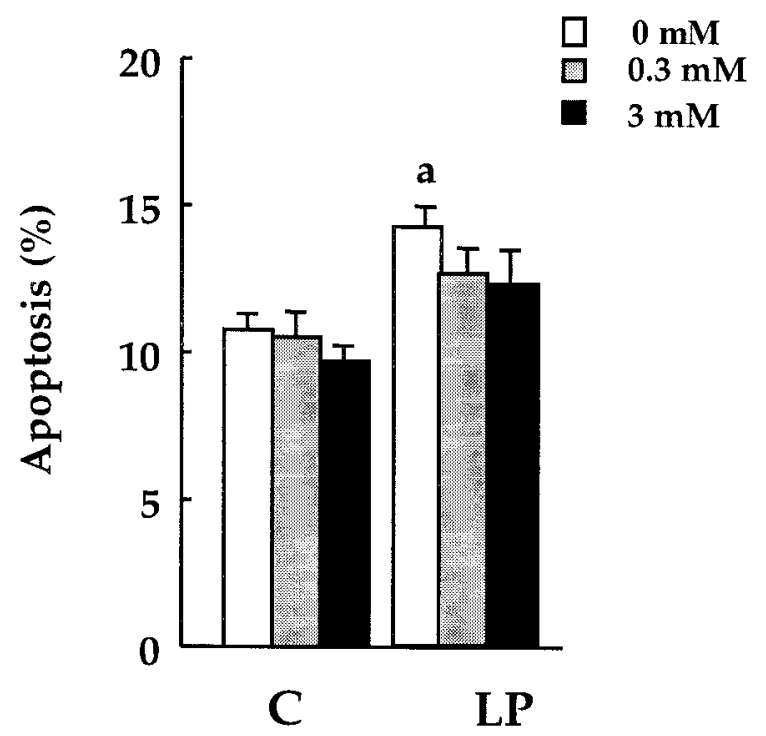

Figure 3 Effect of taurine, methionine and $\beta$-alanine on SNP-induced apoptosis of control (C) and LP group fetal islet cells. Islets from both groups were treated on the 5th day of culture without $(0 \mathrm{mM})$ or with taurine at 0.3 or $3 \mathrm{mM}(\mathrm{a})$, methionine $0 \cdot 1$ or $1 \mathrm{mM}$ (b) or $\beta$-alanine 0.3 or $3 \mathrm{mM}$ (c) for $24 \mathrm{~h}$ before SNP $(100 \mu \mathrm{M})$ treatment. Treatment with the amino acids was maintained during SNP treatment. Apoptosis was quantified by confocal microscopy using a TUNEL method. Values are the means of 12-14 islets pooled from three separate experiments with at least 2800 cells/group. ${ }^{a} P<0 \cdot 01$ compared with control; ${ }^{\mathrm{b}} \mathrm{P}<0 \cdot 01$ compared with $0 \mathrm{mM}$ of the respective amino acid.

taurine in both physiological and supraphysiological concentrations significantly decreased the number of islet cells positive for apoptosis.

Effect of taurine supplementation of the diet of the mother on SNP or IL-1 $\beta$-induced apoptosis

To investigate the effect of a dietary supplementation of taurine, the amino acid was added to the drinking water of the dams during gestation and fetal islets were pretreated or not with taurine for $24 \mathrm{~h}$ and exposed to IL-1 $\beta$ for $24 \mathrm{~h}$ 


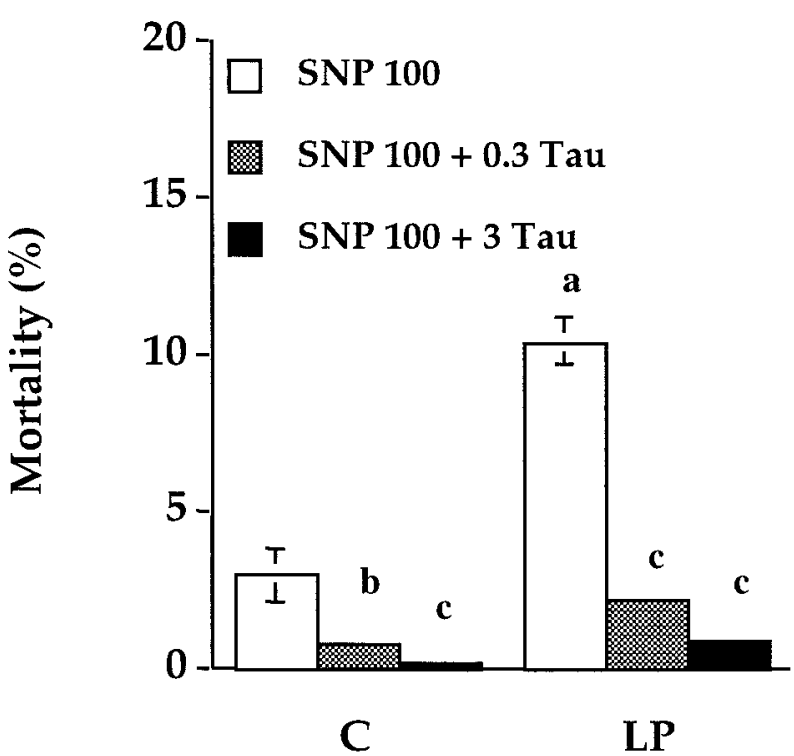

Figure 4 Effect of taurine on the mortality of fetal islet cells induced by SNP. Islets were treated with taurine (Tau, 0.3 or $3 \mathrm{mM}$ ) for $42 \mathrm{~h}$. In the last $18 \mathrm{~h}$ of taurine treatment, SNP $(100 \mu \mathrm{M})$ was added. Mortality was quantified by confocal microscopy using permeant probes as described in Materials and Methods. Values are the means of islets pooled from three separate experiments with at least 2400 cells/group. ${ }^{\text {a }} P<0 \cdot 01$ compared with control; ${ }^{b} P<0 \cdot 05,{ }^{c} P<0 \cdot 01$ compared with $0 \mathrm{mM}$ of taurine.

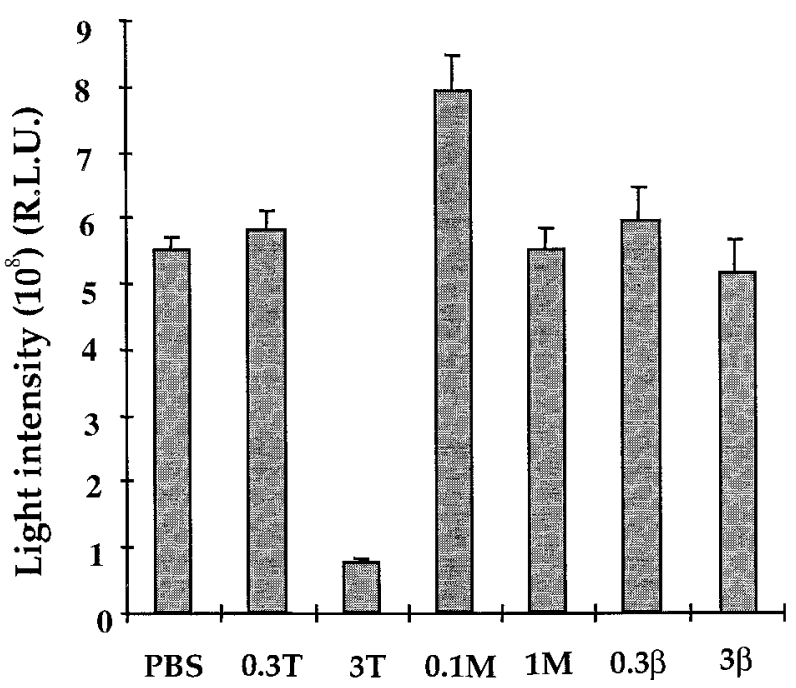

Figure 5 Quenching of peroxynitrite formation by amino acids. After a mixture of luminol and $\mathrm{SIN}-1$ as a source of peroxynitrite, taurine $(T, 0.3$ or $3 \mathrm{mM})$, methionine $(\mathrm{M}, 0 \cdot 1$ or $1 \mathrm{mM})$ or $\beta$-alanine $(\beta, 0.3$ or $3 \mathrm{mM})$ were added. Chemiluminescence of luminol was recorded over $20 \mathrm{~min}$. The figure shows the means of seven replicates.

or to SNP for $18 \mathrm{~h}$. In the control group (Fig. 7a), comparison between the results without or with taurine supplementation of the dam's diet shows that this supple-

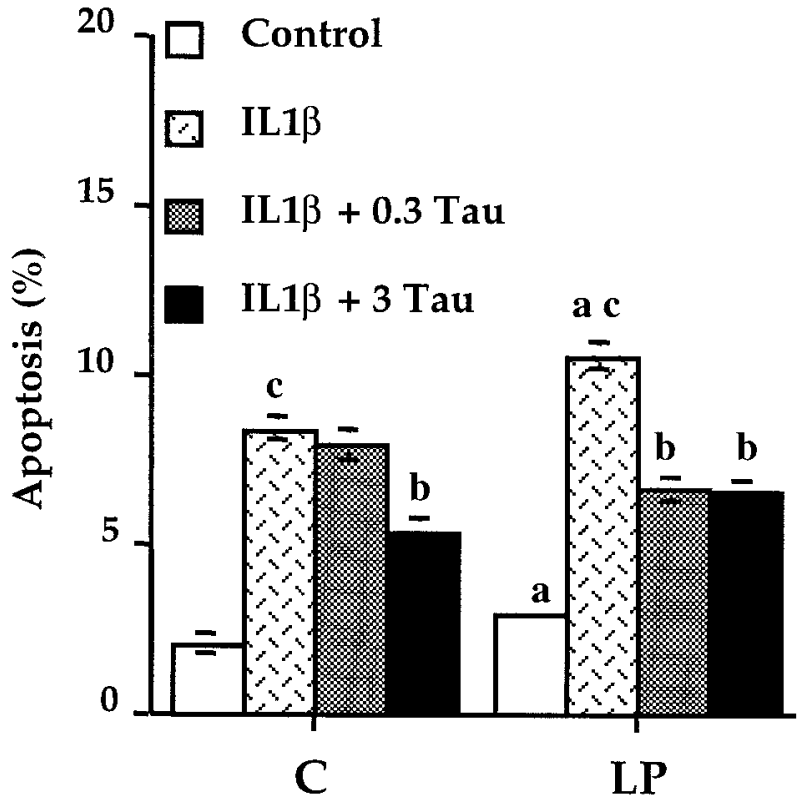

Figure 6 Sensitivity of fetal islets from control (control) and LP groups to IL-1 $\beta$, and protective effect of taurine (Tau) against this toxicity. On the 5 th day of culture, islets were incubated with taurine $(0.3$ or $3 \mathrm{mM})$ for $48 \mathrm{~h}$. IL- $1 \beta(50 \mathrm{U} / \mathrm{ml})$ was added for the last $24 \mathrm{~h}$. Apoptosis was quantified by confocal microscopy using a TUNEL method. Values are the means of 13-20 islets pooled from three separate experiments with at least 3000 cells/group. ${ }^{\mathrm{a}} \mathrm{P}<0.05$ compared with control; ${ }^{\mathrm{b}} \mathrm{P}<0.01$ compared with IL- $1 \beta$ alone; ${ }^{c} P<0.01$ compared with control.

mentation increased the basal rate of apoptosis. Taurine supplementation of the diet of the mother had no effect on the sensitivity of control fetal islets to SNP. In this case, addition of taurine to the culture medium had the same protective effect on the cytotoxicity of SNP with or without taurine supplementation of the dam's diet. This supplementation, however, significantly decreased the cytotoxicity of IL-1 $\beta$ on the control islets. The protection against IL- $1 \beta$ produced by taurine added to the culture medium was further enhanced when the mother had received taurine in the drinking water. In the LP group fetal islets (Fig. 7b), taurine supplementation of the dam's diet significantly decreased the toxicity of SNP and suppressed the toxic effect of IL-1 $\beta$. In the case of taurine supplementation of the dam's diet, the addition of taurine to the culture medium had a cumulative protective effect against SNP.

When taurine is supplemented in the diet of the mother, rate of apoptosis after SNP or IL-1 $\beta$ attack is lower in the LP islets than in control islets, notwithstanding the addition of taurine to the culture medium.

\section{Discussion}

The present study demonstrates for the first time that malnutrition and, more precisely, protein restriction 
a)

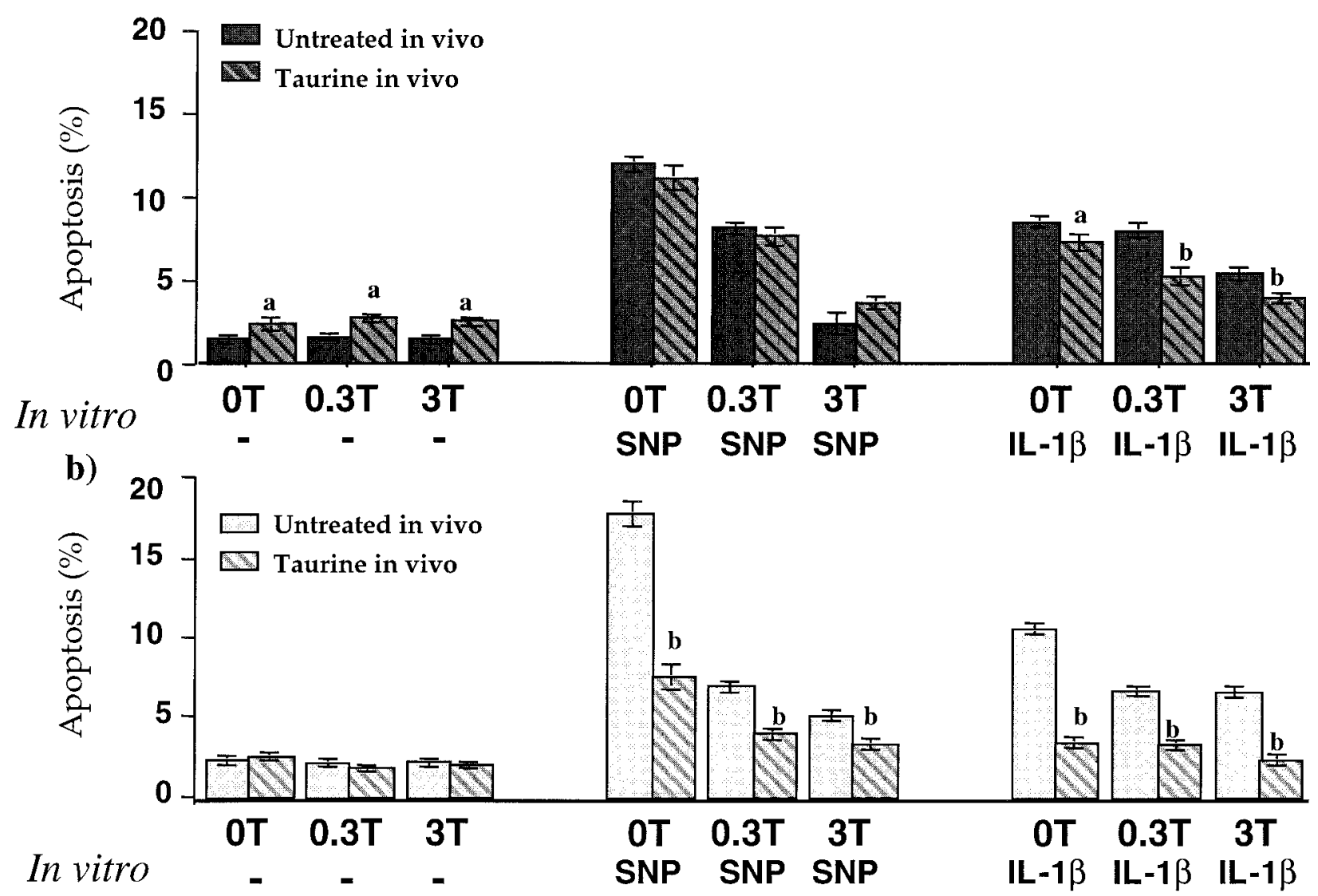

Figure 7 Effect of taurine supplementation on the sensitivity of fetal islet cells from the control group (a) and the LP group (b) to the toxicity of SNP and IL-1 $\beta$. Taurine $(2 \cdot 5 \%)$ was added to the drinking water of the dams during gestation. On the 5 th day of culture, islets were pretreated with taurine $(0.3$ or $3 \mathrm{mM})$ for $24 \mathrm{~h}$ and then treated with IL-1 $\beta(50 \mathrm{U} / \mathrm{ml})$ for $24 \mathrm{~h}$ or with SNP for $18 \mathrm{~h}$. Apoptosis was quantified by confocal microscopy using a TUNEL method. Values are the means of 19 or 20 islets pooled from three separate experiments with at least 4500 cells/group. ${ }^{\mathrm{a}} P<0 \cdot 05,{ }^{\mathrm{b}} P<0 \cdot 01$, compared with untreated in vivo.

during gestation increases the susceptibility of fetal $\beta$-cells to the damage caused by IL-1 $\beta$ and NO, and low taurine concentrations are involved in this alteration.

We have shown previously that a low-protein diet given to pregnant dams increases the rate of apoptosis in vivo in fetal and neonatal islet cells (Petrik et al. 1999). A similarly increased rate of apoptosis in LP fetal islets was also found after 7 days of culture in vitro in the same culture conditions as for controls and after withdrawal from the altered maternal environment. This demonstrates a form of 'programming' of the islet cells in conditions of intrauterine protein malnutrition, which induced long-lasting effects. It is known that IL- $1 \beta$ alone or in combination with TNF- $\alpha$ plus IFN- $\gamma$ induces apoptosis in mouse, rat and human $\beta$-cells (Delaney et al. 1993, 1997, Cetkovic \& Eizirik 1994, Rabinovitch \& Suarez-Pinzon 1998). In this study, an increase in apoptosis after exposure to IL-1 $\beta$ was observed in both groups, but the level was greater in LP group islets than in control islets. It is thus clear that a low-protein diet during gestation augments the sensitivity of fetal $\beta$-cells to IL $1-\beta$.

One pathway that has been proposed as being the effector for IL-1 $\beta$-induced apoptosis is the stimulation of inducible NO synthase (Corbett et al. 1991, Delaney et al. 1993). Therefore, the NO donor SNP was applied in two different concentrations. A dose-dependent increase in apoptosis was observed in islet cells of both groups, but it was more severe in LP islets with high concentrations of SNP. The same was true when another mortality test, based on permeabilization of the cell membrane, was used.

SNP is a complex of ferrous iron $\left(\mathrm{Fe}^{2+}\right)$ with five cyanide anions $\left(\mathrm{CN}^{-}\right)$and a nitrosonium $\left(\mathrm{NO}^{+}\right)$ion. It can simultaneously liberate $\mathrm{NO}$ and an iron moiety capable of generating $\mathrm{OH}^{\bullet}$ radicals via the Fenton reaction (Bates et al. 1991). In order to verify that the cytotoxicity of SNP was not mainly attributable to this 
highly reactive $\mathrm{OH}^{\bullet}$ radical, we added desferrioxamine (DFO), an iron chelator, to the culture medium. DFO partially reduced the rate of apoptosis in both groups of islets, but this reduction accounted only for about $30 \%$ of the apoptosis induced by the high dose of SNP (data not shown). The major part of the toxic effect of SNP appears, then, to be mediated by NO. This result shows that consumption of a low-protein diet during gestation generates a $\beta$-cell mass with greater sensitivity to nitric oxide. The reasons for this increased sensitivity to NO and IL-1 $\beta$ are unknown, but several explanations could be proposed. The lower concentration of insulin-like growth factors (IGFs)-I and -II in the LP islets could be incriminated in their increased sensitivity. Indeed, maternal low protein induces a lower number of islet cells positive for IGFs-I and -II in the progeny (Petrik et al. 1999), and these growth factors have been proposed to be survival factors for the $\beta$-cell (Petrik et al. 1998). The greater sensitivity can also be related to the fact that a low-protein diet during gestation leads to the formation of an islet cell population that matures differently. It has been reported that the sensitivity of $\beta$-cells to IL-1 $\beta$ and streptozotocin is an acquired trait during $\beta$-cell maturation (Nielsen et al. 1999). It has also been reported that cytokines were consistently found to induce iNOS positively in only a sub-population of $\beta$-cells (Eizirik \& Pavlovic 1997). In the LP islets, however, the number of cells expressing iNOS appears to be unaffected, but this does not mean that the concentration of iNOS per cell is not modified. A lowprotein diet can also perturb the expression of several proteins, among them heat-shock protein 70 (hsp70), a protein known to be very important for the protection of $\beta$-cells against the toxicity of NO and IL-1 $\beta$ (Burkart et al. 2000). Finally, as taurine has antioxidant properties, the low concentration found in the LP islets could lead to a less efficient defence against reactive oxygen species.

The second part of the study demonstrated that taurine in physiological or supraphysiological concentrations protects fetal islet cells against the cytotoxicity induced by IL-1 $\beta$ and a NO donor. Methionine also demonstrated a protective effect, but it was less marked than that of taurine. These two amino acids are physicochemically different: taurine possesses a more acidic function $\left(\mathrm{pK}_{\mathrm{a}}\right.$ 1.5) than methionine $\left(\mathrm{pK}_{\mathrm{a}} 2 \cdot 28\right)$ (Wright et al. 1986). This difference is expected as a result of the presence of the sulphonate ion within the taurine acidic function (Wright et al. 1986) and this might explain the different biological activities of taurine and methionine. Moreover, $\beta$-alanine, a structural analogue of taurine that lacks the sulphur moiety, was tested and no protective effect was observed. This indicates that the sulphur group of taurine is responsible for its protective effect against the fetal $\beta$-cell damage induced by NO.

It has been suggested that taurine acts directly as an antioxidant by quenching reactive oxygen species, or indirectly by preventing the increase in membrane per- meability resulting from oxidant injury by a mechanism that remains under discussion (Chesney 1985, Banks et al. 1992). In the present conditions, the protection by taurine cannot be attributed to an inhibition of NO release from the NO donor, but rather, partially to a blocking of peroxynitrite formation. A decrease in chemiluminescence has, indeed, been observed in an acellular system in the presence of the amino acid, but in a high dose. Other mechanisms must also be evoked. In islets, the cytokine IL-1 $\beta$ induces coexpression of iNOS and cyclooxygenase (COX) (Corbett et al. 1993). Taurine chloramine, which is derived from the interaction of taurine with $\mathrm{HOCl} /$ $\mathrm{OCl}^{\bullet}$, a product of myeloperoxidase activity, has been shown to inhibit iNOS and COX2 expression in activated C6 glial cells (Liu et al. 1998). Heat shock protein (hsp)70 has been implicated in the defence of $\beta$-cells against cytokine injury (Scarim et al. 1998). Taurine might enhance the expression of hsp70 to prevent $\beta$-cell destruction by NO and IL-1 $\beta$. It has been shown that taurine protects liver parenchymal cells against heat injury via regulation of hsp70 expression (Kurz et al. 1998).

The effect of taurine on the fetal islets treated by IL-1 $\beta$ differed in the control and LP groups. In control islets, only a high dose of taurine significantly decreased the rate of apoptosis, whereas in LP islets, taurine in both physiological and supraphysiological concentrations significantly decreased the rate of apoptosis. As the LP group islets originated from a low-taurine environment, this could have decreased the threshold of their sensitivity to taurine.

The protective action of taurine in vitro is less apparent when islets are treated with IL-1 $\beta$ than with the NO donor. This might be due to the fact that the stimulation of iNOS leading to production of NO mediates in part, but not completely, the cytotoxicity of IL-1 $\beta$ towards $\beta$-cells. Indeed, in vivo, IL-1 $\beta$ can also stimulate (Yamada et al. 1996, Loweth et al. 1998, Amrani et al. 2000, Zumsteg et al. 2000) the apoptosis of $\beta$-cells by inducing Fas expression. It has been suggested that, when human islet cells are primed by IL- $1 \beta$ to undergo apoptosis, this involves the close association between cell-surface Fas and its ligand (Loweth et al. 1998, Amrani et al. 2000). Others report that IL- $1 \beta$ in combination with TNF- $\alpha$ and IFN- $\gamma$ induces apoptosis of mouse and NIT-1 $\beta$-cells by two independent pathways, NO production and Fas surface expression (Zumsteg et al. 2000). At first sight, the presence of the Fas ligand is unlikely in our cultures, which did not contain significant elements of the immune system. However, $\beta$-cells appear to be able to express FasL themselves, as it has been reported that the destruction of $\beta$-cells in non-obese diabetic mice implies an interaction between Fas induced by cytokines and possibly FasL-expressing $\beta$-cells themselves (Suarez-Pinzon et al. 1999). In contrast, it has been found that cytokines can stimulate apoptosis of cells such as epithelial HT-29 cells, independently of $\mathrm{NO}$ formation but via another pathway activating caspases-8 and -3 (Wright et al. 1999). 
Finally, our findings show that addition of taurine to the drinking water of dams throughout gestation decreases the sensitivity of control fetal islets to IL-1 $\beta$. In LP islets, taurine supplementation decreased the effect of SNP and suppressed the toxicity of IL-1 $\beta$. IGFs-I and IGF-II are considered to be survival factors for $\beta$-cells, and islets exposed to IL-1 $\beta$ do, indeed, exhibit less apoptosis when treated with IGFs (Petrik et al. 1998). We report that supplementation of the maternal diet with taurine restored to normal the number of cells positive for IGF-II in LP islets and enhanced that number in control islets (Boujendar et al. 2000). A similar positive action of taurine on IGF-I production has also been described in other experimental conditions, in which taurine supplementation given to elderly rats restored a normal concentration of IGF-I (Dawson et al. 1999). Therefore, in our experiments, taurine supplementation could have led to a $\beta$-cell population less sensitive or insensitive to IL-1 $\beta$.

The increased basal rate of apoptosis observed in vitro in islets of fetuses from mothers fed a $20 \%$ protein diet supplemented with taurine could be attributed to a difference in the fetal $\beta$-cell population generated by taurine supplementation during development: this $\beta$-cell population could be more mature than that of control fetal islets. Indeed, islets of fetuses from mothers fed a $20 \%$ protein diet supplemented with taurine do secrete insulin in response to glucose challenge, whereas normal fetal islets do not (Cherif et al. 1998).

In view of our findings, the greater sensitivity of LP group islets and the lower taurine concentration in these islets may suggest that a lack of taurine may be involved in the increased rate of apoptosis.

In conclusion, we have demonstrated that a low-protein diet during development increases the sensitivity of fetal $\beta$-cells to NO and IL-1 $\beta$. Taurine may prevent this damage.

\section{Acknowledgements}

The authors thank Marie-Thérèse Ahn for technical assistance. Dr Kathy Jaworski and Dr Jean-Francois Rees are acknowledged for their help in NO assay and peroxynitrite assay. We also thank Dr Rafael Martin del Rio for HPLC measurement.

This work was supported by a grant from the Parthenon Trust, London, UK and a grant from the 'Fonds National de Recherche Scientifique' of Belgium.

\section{References}

Amrani A, Verdaguer J, Thiessen S, Bou S \& Santamaria P 2000 IL1 $\alpha$, IL1 $\beta$, and IFN $\gamma$ mark $\beta$-cells for Fas-dependent destruction by diabetogenic CD4+ T lymphocytes. Journal of Clinical Investigation 105 459-468.
Banks MA, Porter DW, Martin WG \& Castranova V 1992 Taurine protects against oxidized injury to rat alveolar pneumocytes. In Taurine, pp 341-354. Eds JB Lombardini, SW Schaffer \& J Azauma. New York: Plenum Press.

Barker DJP 1998 Mothers, Babies and Health in Later Life. London: Churchill Livingstone.

Barker DJP, Hales CN, Fall CHD, Osmond C, Phipps K \& Clark PMS 1993 Type 2 (non-insulin dependent) diabetes mellitus, hypertension and hyperlipidemia (syndrome $\mathrm{X}$ ): relation to reduced fetal growth. Diabetologia 36 62-67.

Bates JN, Baker MT, Gerra RJR \& Harrison DG 1991 Nitric oxide generation from nitroprusside by vascular tissue: evidence that reduction of the nitroprusside anion and cyanide loss are required. Biochemical Pharmacology 42 (Suppl) S157-S165.

Bonner-Weir S, Trent DF, Honey RN \& Weir GC 1981 Responses of neonatal rat islets to streptozotocin: limited $\beta$-cell regeneration and hyperglycemia. Diabetes 30 64-69.

Boujendar S, Reusens B, Hoet J-J \& Remacle C 1999 Effect of amino acids on $\beta$-cells and endothelial cells proliferation and in vitro interaction between the two cell types. Diabetologia 42 (Suppl 1) A152.

Boujendar S, Remacle C, Hill D \& Reusens B 2000 Taurine supplementation to the low protein maternal diet restores a normal development of the endocrine pancreas in the offspring. Diabetologia 43 (Suppl 1) A128.

Burkart V, Liu H, Bellmann K, Wissing D, Jäättelä $M$, Cavallo $M G$, Pozzilli P, Briviba K \& Kolb H 2000 Natural resistance of human $\beta$-cells towards nitric oxide is mediated by heat shock protein 70 . Journal of Biological Chemistry 275 19521-19528.

Bustamante J, Alonso FJ, Lobo MV, Gine E, Tamarit-Rodriguez J, Solis JM \& Martin del Rio R 1998 Taurine levels and localization in pancreatic islets. Advances in Experimental Medicine and Biology 442 65-69.

Cetkovic CM \& Eizirik DL 1994 TNF- $\alpha$ and IFN- $\delta$ potentiate the deleterious effects of IL- $1 \beta$ on mouse pancreatic islets mainly via generation of nitric oxide. Cytokines 6 399-406.

Cherif H, Reusens B, Ahn MTh, Hoet J-J \& Remacle C 1998 Effects of taurine on the insulin secretion of rat fetal islets from dams fed a low protein diet. Journal of Endocrinology 159 341-348.

Chesney RW 1985 Taurine: its biological role and clinical applications. Advances in Pediatric Infectious Diseases 32 1-42.

Corbett JA, Lancaster JR Jr, Sweetland MA \& McDaniel ML 1991 IL-1 $\beta$ induced formation of EPR-detectable iron nitrosyl complexes in islets of Langerhans. J. Biological Chemistry 266 21351-21354.

Corbett JA, Kwon G, Turk J \& McDaniel ML 1993 IL-1 $\beta$ induces the coexpression of both nitric oxide synthase and cyclooxygenase by nitric oxide. Biochemistry 32 13767-13770.

Dahri S, Snoeck A, Reusens B, Remacle C \& Hoet J-J 1991 Islet function in offspring of mothers on low protein diet during gestation. Diabetes 40 (Suppl 2) 115-120.

Dawson R Jr, Liu S, Eppler B \& Patterson T 1999 Effects of dietary taurine supplementation or deprivation in aged male Fischer 344 rats. Mechanisms of Ageing and Development 107 73-91.

Delaney CA, Green MH L, Lowe JE \& Green IC 1993 Endogenous nitric oxide induced by interleukin- $1 \beta$ in rat islets of Langerhans and HIT-T-15 cells causes significant DNA damage as measured by the 'comet' assay. FEBS Letters 333 291-295.

Delaney CA, Pavlovic D, Hoorens A, Pipeleers D \& Eizirik DL 1997 Cytokines induce deoxyribonucleic acid strand breaks and apoptosis in human pancreatic islet cells. Endocrinology 138 2610-2614.

Eizirik DL \& Pavlovic D 1997 Is there a role for nitric oxide in $\beta$-cell dysfunction and damage in IDDM? Diabetes 13 293-307.

Fehsel K, Jalowy A, Qi S, Birkart V, Hartmann B \& Kolb H 1993 Islet cell DNA is a target of inflammatory attack by nitric oxide. Diabetes 42 496-500.

Garofano A, Czernichow P \& Bréant B 1997 In utero undernutrition impairs rat $\beta$-cell development. Diabetologia 40 1231-1234. 
Garofano A, Czernichow P \& Bréant B 1998 ß-Cell mass and proliferation following late fetal and early postnatal malnutrition in the rat. Diabetologia 41 1114-1120.

Huxtable RJ 1992 Physiological actions of taurine. Physiological Reviews 72 101-163.

Jacobsen JG \& Smith JRLH 1968 Biochemistry and physiology of taurine and taurine derivatives. Physiological Reviews 48 424-511.

Kurz AK, Schliess F \& Haussinger D 1998 Osmotic regulation of the heat shock response in primary rat hepatocytes. Hepatology 28 774-781.

Li X, Traganos F, Melamed MR \& Darzynkiewicz Z 1995 Singlestep procedure for labeling DNA strand breaks with fluorescein- or BODIPY-conjugated deoxynucleotides: detection of apoptosis and bromodeoxyuridine incorporation. Cytometry 20 172-180.

Liu Y, Touna-De Massi M, Park E, Schuller-Levis G \& Quinn MR 1998 Taurine chloramine inhibits production of nitric oxide and prostaglandin E2 in activated C6 glioma cells by suppressing inducible nitric oxide synthase and cyclooxygenate- 2 expression. Brain Research Molecular Brain Research 59 189-195.

Loweth AC, Williams GT, James RFL, Scarpello HB \& Morgan NG 1998 Human islets of Langerhans express Fas ligand and undergo apoptosis in response to interleukin $1 \beta$ and Fas ligation. Diabetes 47 $727-732$.

Mandrup-Poulsen T 1996 The role of interleukin in the pathogenesis of insulin-dependent-diabetes mellitus. Diabetologia 39 1005-1029.

Misko TP, Schilling RJ, Salvemini D, Moore WM \& Currie MGA 1993 Fluorometric assay for measurement of nitrite in biological samples. Analytical Biochemistry 214 11-16.

Mourmeaux JL, Remacle C \& Henquin JC 1985 Morphological and functional characteristics of islets neoformed during tissue culture of fetal rat pancreas. Molecular and Cellular Endocrinology 39 237-246.

Nielsen K, Karlsen AE, Deckert M, Madsen OD, Serup P, Mandrup-Poulsen T \& Nerup J $1999 \beta$-Cell maturation leads to in vitro sensitivity to cytotoxins. Diabetes 48 2324-2332.

Petrik J, Arany E, McDonald TJ \& Hill DJ 1998 Apoptosis in the pancreatic islet cells of the neonatal rat is associated with a reduced expression of insulin-like growth factor II that may act as a survival factor. Endocrinology 139 2994-3004.

Petrik J, Reusens B, Arany E, Remacle C, Coehlo C, Hoet J-J \& Hill DJ 1999 A low protein diet alters the balance of islet cell replication and apoptosis in the fetal and neonatal rat and is associated with a reduced pancreatic expression of insulin-like growth factor-II. Endocrinology 140 4861-4873.
Rabinovitch A \& Suarez-Pinzon WL 1998 Cytokines and their roles in pancreatic islet $\beta$-cell destruction and insulin-dependent diabetes mellitus. Biochemical Pharmacology 55 1139-1149.

Redmong HP, Wang JH \& Bouchier Heyes D 1996 Taurine attenuates nitric oxide and reactive oxygen intermediate dependent hepatocyte injury. Archives of Surgery 131 1280-1288.

Reusens B, Dahri S, Snoeck A, Bennis-Taleb N, Remacle C \& Hoet J-J 1995 Long-term consequences of diabetes and its complications may have a fetal origin: experimental and epidemiological evidence. In Diabetes Nestlé Nutrition Workshop Series, vol 35 pp 187-198. Ed. RM Cowett. New York: Raven Press.

Scarim AL, Heitmeier MR \& Corbett JA 1998 Heat shock inhibits cytokine-induced nitric oxide synthase expression by rat and human islets. Endocrinology 139 5050-5057.

Snoeck A, Remacle C, Reusens B \& Hoet J-J 1990 Effect of low protein diet during pregancy on the fetal rat endocrine pancreas. Biology of the Neonate $\mathbf{5 7}$ 107-118.

Suarez-Pinzon W, Sorensen O, Bleackley RC, Elliott JF \& Rabinovitch RRV $1999 \beta$-Cell destruction in NOD mice correlates with Fas (CD95) expression on $\beta$-cells and proinflammatory cytokine expression in islets. Diabetes 48 21-28.

Wang J-H, Redmond HP, Watson WG, Condrom C \& BouchierHeyes D 1996 The beneficial effect of taurine on the prevention of human endothelial cell death. Shock 6 331-338.

Wright CE, Tallan HH \& Lin Y-Y 1986 Taurine: biological update. Annual Review of Biochemistry 55 427-453.

Wright K, Kolios G, Westwick J \& Ward SG 1999 Cytokine-induced apoptosis in epithelial HT-29 cells is independent of nitric oxide formation. Evidence for an interleukin-13-driven phosphatidylinositol 3-kinase-dependent survival mechanism. Journal of Biological Chemistry 274 17193-17203.

Yamada K, Takane-Gyotoku N, Yuan X, Ichikawa F, Inoda C \& Nonaka K 1996 Mouse islet cell lysis mediated by interleukin 1 induced Fas. Diabetologia 39 1306-1312.

Zumsteg U, Fvigerio S \& Hollander GA 2000 Nitric oxide production and Fas surface expression mediate two independent pathways of cytokine-induced murine $\beta$-cell damage. Diabetes 49 39-47.

Received in final form 8 June 2001

Accepted 9 July 2001 